\title{
Population Drinking and Gender Gap in Suicide Mortality in Russia
}

\author{
Yury E. Razvodovsky \\ Grodno State Medical University, Grodno, Belarus
}

\begin{abstract}
Across most countries, suicide rates are significantly higher for men compared to women, while women typically have higher rate of suicide attempts. The gender difference in the suicide rates is particularly large in the Eastern European countries. There is suggestive evidence of a crucial role of alcohol in explanation of this phenomenon. In present study we will test the hypothesis of the close aggregate level link between alcohol consumption and gender difference in suicide mortality rates in Russia using data on sex-specific suicide rates and alcohol consumption per capita between 1965 and 2015. Time-series analytical modeling techniques (ARIMA) were used to examine the relation between the gender gap in suicide mortality and trends in alcohol consumption per capita. According to the results of time-series analysis, alcohol consumption is a statistically significant factor associated with gender gap in suicide mortality in Russia, implying that a 1-litre increase in consumption per capita is associated with an increase in the difference between male and female suicide mortality rates by $8.3 \%$. The results of the analysis also suggest that $66 \%$ of the difference in suicide mortality between males and females in Russia could be attributed to alcohol. The outcomes of this study provide indirect support for the hypothesis that alcohol is a major contributor to the high gender gap in suicide mortality and its dramatic fluctuations in Russia during the last few decades.
\end{abstract}

Keywords: alcohol consumption, gender gap, suicide rates, Russia, 1965-2015.

Copyright (C) 2017 KBCSM, Zagreb

e-mail: alcoholism.kbcsm@gmail.com•www.http//hrcak.srce.hr/acoholism

\section{Introduction}

Across most countries, suicide rates are significantly higher for men compared to women, although women typically have higher rate of suicide attempts $[1,2]$. Several potential factors have been put forward as the cause of the suicide-gender paradox, includ-

Correspondence to: Yury E. Razvodovsky

Grodno State Medical University, Belarus Gorky Street, Grodno 230009, Belarus

tel.: + 37501527018 84, fax: +3750152 4353 41,

e-mail: razvodovsky@tut.by ing that men choose more lethal methods of suicide and that they are less likely to seek medical help for depression [3].

The gender difference in the suicide rates is particularly large in the Eastern European countries [4]. It is important to point out that, while the gender difference in suicide rates in Western Europe remains relatively stable across time, the Eastern European countries show huge fluctuations in the gender gap [5]. This suggests that although conventional factors may account for some of the gender difference in suicide rates in 
Eastern Europe, it is likely that other factors also contribute to the suicide-gender paradox in this region. Some researchers attribute the high gender gap in suicide rates and its dramatic fluctuations in the Eastern European countries to a higher level of alcohol consumption and binge drinking pattern. It was reported, for example, that the male-female rate ratio of suicides in Belarus is positively associated with the level of vodka consumption per capita [5].

High suicide rate in Russia and its profound fluctuations over the past decades have attracted considerable interest [6,7]. Several studies reported a significant association between alcohol and suicide in this country at the individual and aggregate levels [8-12]. In his time series analysis Stickley and coauthors concluded that binge drinking had a significant association with the occurrence of suicide in Russia and the magnitude of the relation is the same across the course of the later-tsarist, Soviet, and post-Soviet periods [13]. This evidence provides additional support for the hypothesis that unfavorable mixture of higher overall level of alcohol consumption and binge drinking pattern is a major risk factor for suicide mortality in Russia.

It should be mentioned, that the size of the bivariate association between alcohol and suicide for men in Russia is substantially greater than for women. The estimates based on population data suggest that alcohol may be responsible for $61 \%$ of male suicides and $35 \%$ of female suicides in Russia [14]. In relation to this, it seems plausible that the role of alcohol is crucial in understanding the high gender gap in suicide rates in this country.

In present study we will test the hypothesis of the close aggregate level link between alcohol consumption and gender difference in suicide rates in Russia using data on sexspecific suicide rates and alcohol consumption per capita between 1965 and 2015.

\section{Material and methods}

\section{Data}

The data on sex-specific suicide mortality rates (per 1000.000 population) between 1956 and 2015 are taken from the Rosstat (Russian State Statistical Committee). The total level of alcohol consumption (in litres of pure alcohol) in Russia has been estimated using the indirect method based on alcohol poisonings mortality rate $[15,16]$.

\section{Statistical Analysis}

To estimate the relation between changes in population drinking and gender gap in suicide mortality across the study period a time series analysis was performed using the statistical package "Statistica 12. StatSoft." The dependent variable was the gender gap in suicide difference rates and the independent variable was aggregate alcohol consumption. The correlations between the raw data from two time series can often be spurious due to common sources in the trends and due to autocorrelation [17]. In order to reduce the risk of obtaining spurious correlation between variables that have common trends we removed these trends by means of a "differencing" procedure. The procedure which eliminates the systematic variation within a time series is referred to as "prewhitening." We used ARIMA (autoregressive integrated moving average) modeling to estimate the relationship between the time series gender gap in suicide mortality and population drinking in this paper. In addition, the effect of population drinking on gender gap in suicide 
mortality rates will be presented in terms of alcohol-attributable fraction [18].

\section{Results}

According to official statistics, the male suicide rate decreased by $22.8 \%$ (from 447.5 to 345.0 per 1000.000 population), while the female suicide rate decreased by 39.6\% (from 101.0 to 61.0 per 1.000 .000 population) in Russia from 1965 to 2015

The graphical evidence suggests that the temporal pattern of gender gap in suicide mortality fits closely with changes in alcohol consumption per capita.

The trends fluctuated dramatically over time: dropped sharply between 1984 to1986, then jumped dramatically between 1991 and 1994. From 1995 to 1998 there was a fall in rates before they again rose between 1998 and $2001 / 2003$, and then started to decrease.

A Spearman rank correlation analysis suggests a strong association between the gender gap in suicide mortality and alcohol consumption per capita $(r=0.90 ; \mathrm{p}<0,000)$. There were sharp trends in the time series data across the entire study period. These systematic variations were well accounted for by the application of first-order differencing and the specification of a first order moving average parameter

After prewhitening the cross-correlations between alcohol consumption and gender gap in suicide mortality time series were inspected. The outcome indicated statistically significant cross-correlation between the two variables at lag zero $(r=0.73 ; \mathrm{SE}=0.13)$. According to the results of ARIMA analysis,

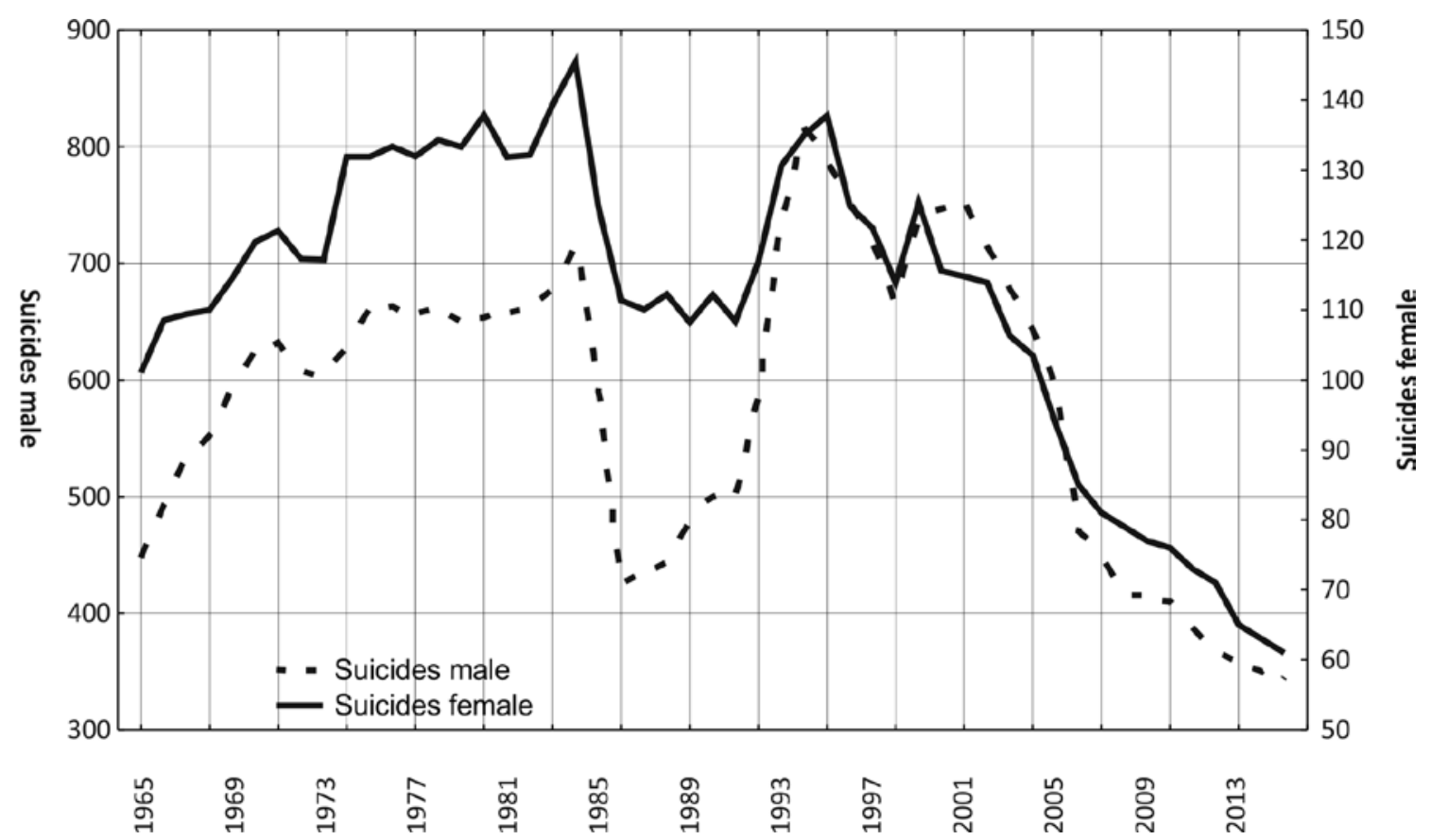

Figure 1. Trends in male and female suicide mortality rates in Russia between 1965 and 2015. 


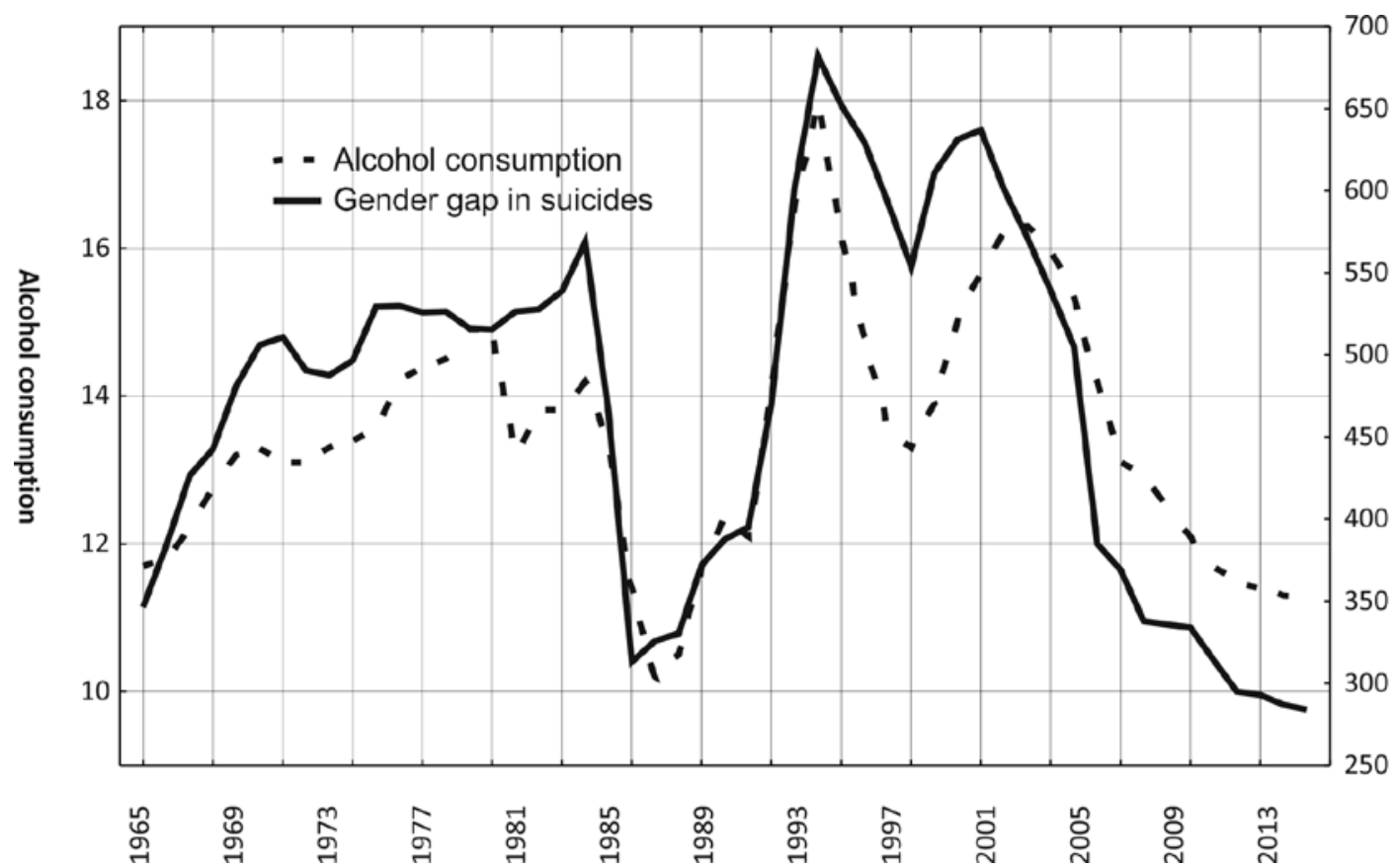

Figure 2. Trends in the gender gap in suicide mortality and alcohol consumption per capita in Russia between 1965 and 2015.

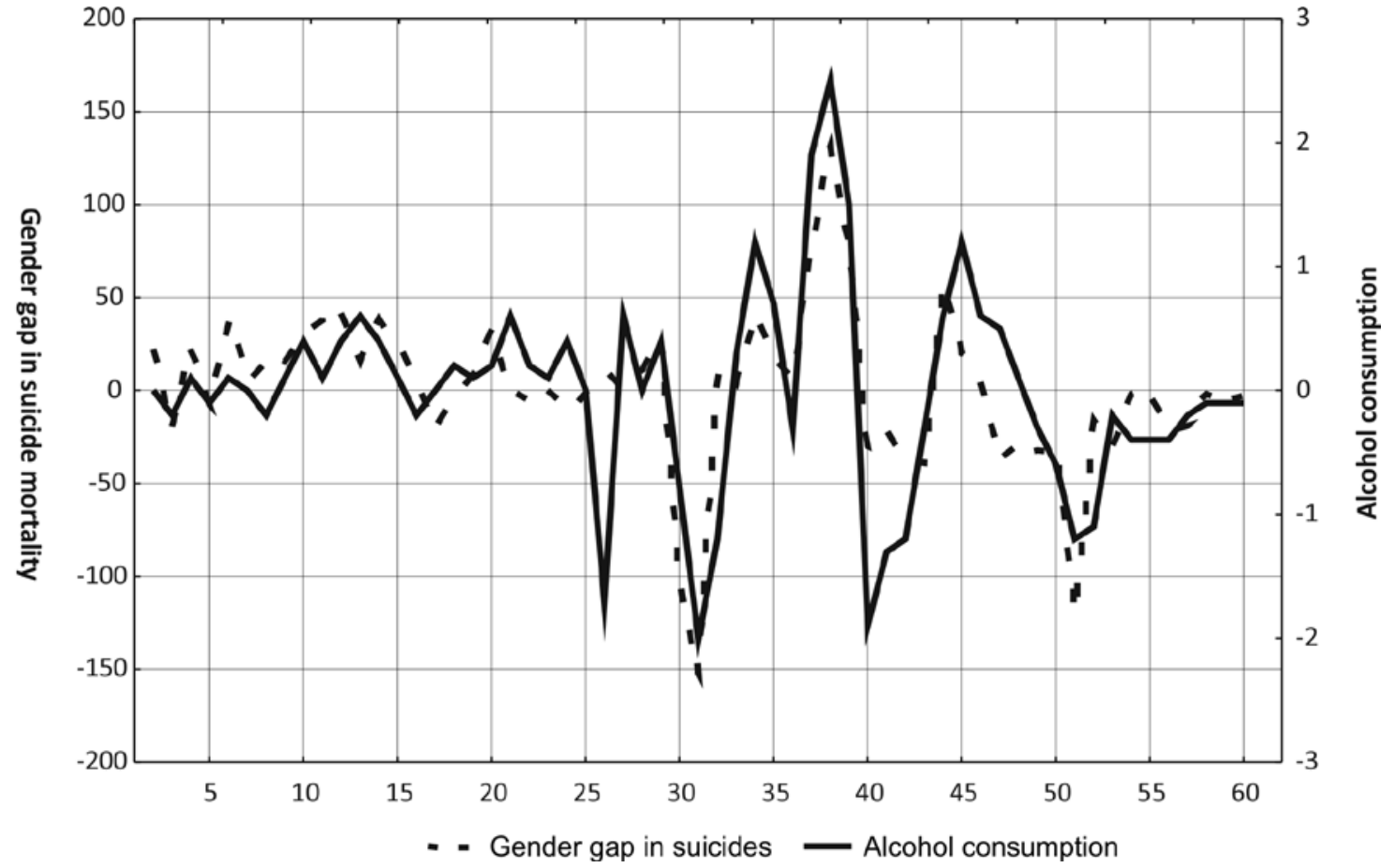

Figure 3. Trends in the gender gap in suicide mortality and alcohol consumption per capita in Russia between 1956 and 2015 after "prewhitening". 
alcohol consumption is a statistically significant factor associated with gender gap in suicide mortality in Russia, implying that a 1-litre increase in consumption per capita is associated with an increase in the difference between male and female suicide mortality rates by $8.3 \%$. The results of the analysis also suggest that $66.0 \%$ of the difference in suicide mortality rates between males and females in Russia could be attributed to alcohol.

\section{Discussion}

The results of the time series analysis, which suggest positive and statistically significant effects of alcohol consumption per capita on gender gap in suicide mortality in Russia between 1965 and 2015 indirectly supports alcohol-related hypothesis. Therefore, a high level of alcohol consumption and binge drinking pattern may help in explaining the high gender gap in suicide mortality and its dramatic variations in Russia during the last few decades.

It should be recognized, however, that ignoring the confounding variables may imply that the effect of population drinking on sex difference in suicide mortality rates is overestimated. It can be assumed that the alcohol consumption effect on gender gap in suicide mortality is a spurious indicator of the impact of other powerful risk factors such as psychosocial distress. It seems that males were more vulnerable to the stressful experience resulting from abrupt socioeconomic

\section{References}

1. Hawton K. Sex and suicide. Gender differences in suicidal behavior. Br J Psychiatry. 2000;177:484-5

2. Razvodovsky YE, Stickley A. Suicide in urban and rural regions of Belarus, 1990-2005. Public Health. 2009;123:27-31.

Population Drinking and Gender Gap in Suicide Mortality in Russia changes throughout the 1990s. Several studies have suggested that men in Russia, as a result of traditional masculine norms, are more prone to respond to stressful situations with maladaptive behavior such as increased alcohol consumption, while women have a more adaptive stress response $[19,20]$. In particular, Cockerham et al. found that in Russia psychological distress promote frequent drinking among men, but not among women, even though women reported significantly more distress [22]. Similarly, Jukkala and coauthors concluded that experiencing several kinds of economic problems is positively related to the risk of binge drinking among Russian men [21]. It might be the case that the psychosocial distress was the main cause of increased demand for alcohol at this time.

In conclusion, the outcomes of this study provide indirect support for the hypothesis that alcohol is a major contributor to the high gender gap in suicide mortality and its dramatic fluctuations in Russia during the last few decades. In relation to this, the Russian government needs to develop the effective alcohol control policy to address the phenomenon of high suicide rates among men.

\section{Acknowledgments}

None

\section{Conflict of interest}

None to declare

3. Murphy GE. Why women are less likely than men to commit suicide. Compr Psychiatry. 1998;39:165-75

4. Möller-Leimkühler AM. The gender gap in suicide and premature death or: why are men so vulnerable? Eur Arch Psychiatry Clin Neurosci. 2003;253:1-8.

Alcoholism and Psychiatry Research 2017;53:115-122 
4. Razvodovsky YE. Suicide trends in Belarus, 19802008. In: Pray, L., Cohen, C., Makinen, I.H., Varnik, A., MacKellar F.L. (Eds.). Suicide in Eastern Europe, the CIS, and the Baltic Countries: Social and Public Health Determinants (pp. 21-28). Viena: Remaprint; 2013.

5. Razvodovsky YE. A comparative analysis of dynamic of suicides in Belarus and Russia. Journal of Belarusian Psychiatric Association. 2008;14:15-9.

6. Varnik A, Wasserman D, Dankowicz M, Eklund G. Age-specific suicide rates in the Slavic and Baltic regions of the former USSR during perestroika, in comparison with 22 European countries. Acta Psychiatr Scand. 1998;20-5.

7. Pridemore WA. Heavy drinking and suicide in Russia. Soc Forces. 2006;85:413-30.

8. Razvodovsky YE. Suicide and fatal alcohol poisoning in Russia, 1956-2005. Drugs: Education, Prevention and Policy. 2006;16:127-39.

9. Razvodovsky YE. The Effects of Alcohol on Suicide Rate in Russia. J Socialomics. 2014;3:112.

10. Razvodovsky YE. Beverage-specific alcohol sale and suicide in Russia. Crisis. 2009;30: 186-91.

11. Razvodovsky YE. Contribution of alcohol in suicide mortality in Eastern Europe. In: Kumar, U. (Ed.). Suicidal behavior: underlying dynamics. New York: Routledge; 2015.

12. Stickley A, Jukkala T, Norstrom T. Alcohol and suicide in Russia, 1870-1894 and 1956-2005: evidence for the continuation of a harmful drinking culture across time? J Stud Alcohol Drugs. 2011;72:341-7.

13. Razvodovsky YE. Alcohol consumption and suicide rates in Russia. Suicidology Online. 2011;2:6774.

14. Nemtsov AV, Shelygin KV. Alcohol consumption in Russia: 1956-2013. The Questions of Narcology. 2015;5:28-32.

15. Nemtsov AV, Razvodovsky YE. The estimation of the level of alcohol consumption in Russia: a review of the literature. Sobriology. 2017;1:78-88.

16. Box GEP, Jenkins GM. Time Series Analysis: forecasting and control. London. Holden-Day Inc. 1976.

17. Norström T. The use of aggregate data in alcohol epidemiology. Br J Addict. 1989;84:969-77.

18. Makinen IH. Suicide mortality of Eastern European regions before and after the communist period. Soc Sci Med. 2006;63:307-19.

19. Gavrilova NS, Semyonova VG, Evdokushkina GN, Gavrilov LA. The response of violent mortality to economic crisis in Russia. Popul Res Policy Rev. 2000;19:397-419.

20. Yukkala T, Makinen IH, Kislitsyna O, Ferlander S. Economic strain, social relations, gender, and binge drinking in Moscow. Soc Sci Med. 2008;66:663-74.

21. Cockerham CW, Hinote BP, Abbot P. Psychological distress, gender, and health lifestyles in Belarus, Kazakhstan, Russia, and Ukraine. Soc Sci Med. 2006;63:2381-94.

\section{Uporaba alkolhola i spolne razlike u stopi samoubojstava u Rusiji}

Sažetak: U većini zemalja stopa samoubojstava je značajno veća u korist muškaraca, dok je kod žena veći broj pokušaja samoubojstava. Spolna razlika u stopama samoubojstava posebno je izražena u istočnoeuropskim zemljama. Postoje snažni dokazi da alkohol ima važnu ulogu u objašnjavanju ovog fenomena. U ovoj studiji ispitat ćemo hipotezu o povezanosti bliske skupine između konzumacije alkohola i spolnih razlika u stopi samoubojstava sa smrtnim ishodom u Rusiji koristeći podatke u odnosu na spolnu određenost za stope samoubojstava i konzumaciju alkohola po glavi stanovnika između 1965. i 2015. godine. Analize vremenskih serija modelarnih tehnika (ARIMA) korištene su za ispitivanje povezanosti između spolnih razlika u stopi samoubojstava i trendova u konzumaciji alkohola po glavi stanovnika. Prema rezultatima analize vremenskih serija konzumacija alkohola je statistički značajan faktor povezan sa spolnom razlikom i stopom samoubojstava u Rusiji, u kojoj se implicira da je povećanje potrošnje od 1 litre po glavi povezano s povećanjem razlike između muške 
i ženske stope samoubojstava sa smrtnim ishodom za 8.3\%. Rezultati analize također sugeriraju da se razlika od 66\% u stopi samoubojstava sa smrtnim ishodom između muške i ženske populacije u Rusiji može pripisati alkoholu. Ishodi studije pružaju indirektnu podršku hipotezi da alkohol uvelike doprinosi visokoj spolnoj razlici u stopi samoubojstava i dramatičnim fluktuacijama u Rusiji tijekom posljednja dva deseljeća.

Ključne riječi: konzumacija alkohola, spolne razlike, stopa samoubojstava, Rusija, 1965-2015 